tute and the French National Centre for Scientific Research.

Except for pharmaceuticals, industrial-scale use of microbes today is largely confined to the manufacture of bread, cheese, wine, and beer. However, the range of things which microbes could produce includes fuels, dyes, vitamins, and the chemical precursors of a host of products ranging from plastics to pesticides. Technical problems, such as keeping large vats of microbes stirred and aerated without damaging them, often prevents a microbe-based manufacturing process from being economically feasible. The Penn State-Pasteur Institute team believes that making the organisms float could improve the economic picture.

According to Dr Bryant, work on the flotation gene began at Penn State in 1984 when Dr Marsac visited him. The two scientists are specialists in the study of Blue-green Algae (Cyanophyta or Cyanobacteria). These 'have internal structures called gas vesicles that are simply spaces within the cell filled with gas,' Dr Bryant explained. 'These "gas balloons" give the cell buoyancy. By balancing the production and destruction of these gas vesicles, cells can position themselves in the ponds where they normally live, to obtain just the right amount of sunlight to make food via photosynthesis.' 'We reasoned that if one could clone the genes for the gas vesicles into other industrially important organisms, one could make them float when wanted. Flotation would make it easier to grow and collect the cells. Ultimately, we want to be able to make mammalian cells float. Mammalian cells are notoriously difficult to process in large quantities because they are so fragile. They are heavy and difficult to stir. If one could make them float, they would be much easier to process.'

In addition to Dr Bryant, the Penn State group includes Dr S. Edward Stevens, associate professor of Microbiology, and Dr Ronald Porter, associate professor of Microbiology and Molecular Genetics.

RALPH KAZARIAN
National Science Foundation
1800 G Street
Washington
DC 20550
USA.

RALPH KaZARIAN $1800 \mathrm{G}$ Street

Washington

USA.

\title{
Environmental Damage Liability: Need for Legal Instruments
}

European Justice Ministers, at a meeting in Oslo during 17-19 June 1986, stressed the need for adequate measures to protect the environment, and underscored the international nature of environmental pollution to which the Norwegian Prime Minister, Mrs Gro Harlem Brundtland, also referred in her opening address to the Ministers. She commented further: 'Our peoples have recently been shaken by the catastrophe in Chernobyl-[which] underlines the fact that we are all dependent upon one another for our security in a wide sense, indeed for our future'.

Recognizing that damage to the environment will never be entirely prevented in all cases, the Ministers said it was essential that adequate compensation be given for damage suffered. They noted the need for a civil liability regime based on presumption of fault or strict liability, and for a collective compensation system based on insurance or a fund.

Other measures advocated by the European Justice Ministers include compulsory restoration or cleaning up of the damaged environment, especially where the general interest is affected. They also called on the Council of Europe to give high priority to the problem of compensation for damage to the environment, with a view to preparing an appropriate legal instrument.

\section{Directorate of Press AND INFORMation Council of Europe \\ B.P. $431 R 6$ \\ F-67006 Strasbourg Cedex \\ France.}

\section{Simulating a Major Disaster in Europe: Studying the Lessons of Chernobyl}

The Ministers of southern Europe* who are responsible for preventive action and protection against major disasters, met for the third time in Ravello (Italy) on 24 and 25 May 1986, at the invitation of the President of the European University Centre for the Cultural Heritage in Ravello, Professor Jacques Soustelle, and with support from the Council of Europe. Studying the lessons of recent major disasters, in particular Chernobyl, they hope that each of the countries concerned will set up an information unit responsible for:

- Collecting data in the competent departments;

- Making these data available to nongovernmental users;

- Carrying out the necessary syntheses for information of governments; and

- Ensuring that government announcements are expressed in a coherent and consistent fashion.

The activity of these national units must be coordinated at European level with a view to standardizing information

\footnotetext{
* Portugal, Spain, France, Italy, San Marino, Greece, Malta, Cyprus, and Turkey.
}

procedures in the event of major disasters.

A joint disaster simulation exercise will be carried out early in 1987 to contribute to the preparation of a homogeneous doctrine by the various countries concerned, and to test the machinery for information and cooperation to be used in organizing assistance between the countries of southern Europe.

The exercise-to-be is defined as follows:

- Pilot country: Italy;

- Type of disaster simulated: destruction of industrial installations by a major earthquake releasing highly toxic chemical materials over the ground and into the sea and air in a coastal tourist region;

- Preparation of the exercise: cooperation between Italy and France to decide on the location and details of the exercise; and

- Information: to all the countries of southern Europe taking part in the exercise, particularly regarding cooperation in organizing assistance.

Approval was also given for the establishment in the Republic of San Marino of a European Centre for Medical Care in Disasters. The centre will be responsible for preparing information programmes, and for training and 
study programmes on organization of assistance in the event of major disasters.

The task of establishing and standardizing the terminology relating to major disasters has been entrusted to the Spanish delegation, which will present this proposal at the next meeting, to be held on 1 and 2 December 1986 in Istanbul, at the invitation of the Turkish Government. The fifth informal meeting of the Ministers might be held in Greece, at the invitation of the Greek Government, which will be setting up a European pilot centre for forecasting earthquakes.

The parliamentary Assembly of the Council of Europe is following with especial interest the work done in the fields of forecasting and prevention of disasters, and also on cooperation between the states of southern Europe-not only to forecast disasters, but also to protect and safeguard the cultural heritage.

\section{The Centre For Science and Environment in India}

The Centre for Science \& Environment (CSE) was set up in 1980 in New Delhi as a non-profit, non-governmental, quasi-academic, research organization. Its aim is to promote public awareness of the role of science and technology in Indian national development. More specifically, it explores issues concerning environment and development in India.

It was founded by Anil Agarwal, an Indian Institute of Technology graduate who had worked as a journalist on 'The Hindustan Times' and the 'Indian Express' in Delhi and as the Assistant Editor of the Earthscan feature agency in London. Most of the research and writing staff of the CSE are science graduates or journalists.

One of the first activities for the CSE was to run a feature service for newspapers. In 1982, it published the State of India's Environment-A Citizens' Report, which for the first time examined not only different facets of the deterioration of the country's environment in painstaking detail but also established the interconnection between those different facets. The report, published as a hardback volume of nearly 200 pages, won acclaim in India and abroad, and has become the biggest single source of information on the country's environment.

* Being reviewed for our Journal by Dr M.S. Swaminathan, FRS, FNA, Director-general of the International Rice Research Institute and President of IUCN. - Ed.

Nore: We would like to commend this initiative most warmly and express the ardent hope that it will be emulated in more and more countries having similarly enlightened heads of Government who are disposed to seek independent expert advice on pressing or foreseeable environmental problems. $-\mathrm{Ed}$.
Three years later, the CSE followed up with a second report*, which covered new ground and dealt with new problems, and which included a long section on the causes and consequences of the Bhopal gas-leak tragedy. It has already sold some 5,000 copies and is exactly twice as voluminous as the first book. Like the first Report, it has been widely extracted and reviewed in the Indian and foreign press. Prime Minister Rajiv Gandhi has recently asked the CSE, on the basis of the second Report, to brief the entire Indian Cabinet of Ministers and all the Members of Parliament on the threat to India's environment. Yet another publication of CSE is Temples Or Tombs? by the undersigned, which deals with three industrial projects that triggered off environmental controversies in the country.

One of the remarkable features of CSE's activities is that it has until recently been able to support itself almost entirely by the sales of its books. It is now working on others, two of which are to be entitled 'India's Cooking Energy Crisis' and the 'State of India's Urban Environment'. The CSE also does networking on environmental issues with NGOs in India and abroad.

\section{Energy from a Fishpond}

Falling oil prices make little difference to poor farmers in the Third World whose resources cannot be stretched to buy power at any price and who, all too frequently, are remote from principal sources of supply. Hence the interest of a UNESCO enterprise in Paraguay, to develop a device for on-farm supplies of energy from biogas.

The biogas is produced by the breakdown of aquatic plants from a fishpond. Microorganisms work on the aquatic plants (which can be supplemented with animal manure) to decompose them in a biodigester (see caption to Fig. 2) in which organic matter is further decomposed. It is based on a Chinese model, and yields around nine cubic metres of gas a day.

Integrating the installation with a fishpond has several advantages: it helps the farmer to raise his energy capacity with the biogas, and it also increases his foodstocks with fish from the pond, as well as supplying fertilizers and animal fodder from the aquatic plants.

UNESCO's Regional Office for Science and Technology (ROSTLAC) in Montevideo helped to develop the system, which was designed by research workers at the Institute of Basic Sciences in the National University at Asuncion, led by Dr R. Fitzpatrick, a former UNESCO official. The installation has been set up at the Enrique de Osso College for the Promotion of Rural Women in Asuncion.

The students, who come from inland regions of the country, will spread the idea in their own villages. A training course for peasants together with instruction manuals are foreseen. 